\title{
Analysis of Women Farmers' Contributions to Agricultural Production in Akinyele Local Government Area of Oyo State, Nigeria
}

\author{
F. A. Alaka ${ }^{1, *}$ W. O. Oyediran ${ }^{2}$, A. S. Alaka ${ }^{3}$ \\ ${ }^{1}$ Department of Agricultural Education, School of Secondary Education (Voc. \& Tech. Programmes), FCES, Oyo, Oyo State, \\ Nigeria. \\ ${ }^{2}$ Department of Agricultural Extension and Rural Development, Federal University of Agriculture, Abeokuta, Ogun State, Nigeria. \\ ${ }^{3}$ School of Secondary Education (Special Programmes), FCES, Oyo, Oyo State, Nigeria.
}

\begin{abstract}
How to cite this paper: F. A. Alaka, W. O. Oyediran, A. S. Alaka. (2020) Analysis of Women Farmers' Contributions to Agricultural Production in Akinyele Local Government Area of Oyo State, Nigeria. International Journal of the Science of Food and Agriculture, 4(3), 348-353. DOI: 10.26855/ijfsa.2020.09.015
\end{abstract}

Received: September 2, 2020

Accepted: September 25, 2020

Published: October 12, 2020

*Corresponding author: F. A. Alaka, Department of Agricultural Education, School of Secondary Education (Voc. \& Tech. Programmes), FCES, Oyo, Oyo State, Nigeria.

Email: fayoade2013@gmail.com

\begin{abstract}
Researches on agriculture and implementation of its outcomes are replete towards the acknowledgement of women farmers' contributions to food security as mother, wives, and stakeholders. This study analysed contributions of women farmers to Agricultural Production in Akinyele Local Government Area of Oyo State, Nigeria. Purposive sampling was used in the selection of respondents and structural questionnaire was administered to a total of one hundred and fifty respondents. Data collected were analysed using descriptive and inferential statistics. The study disclosed that women are active participants in both agricultural and non-agricultural activities (38.6\%). It was found that $73.3 \%$ of the respondents used traditional implements for the agricultural activities (26.7\%). Problem of land tenure (56\%) and inadequate seeds (48.7\%) affected the agricultural productivity of the rural women in the study area. Regression results showed that age $(\beta=0.74)$, marital status $(\beta=0.12)$, income $(\beta=0.18)$ and educational level $(\beta=0.81)$ are determinants of rural women participation in agricultural activities at $p<0.05$. Based on these findings, it was recommended that government should intensify effort at providing, basic farm inputs, modern implements, and institutional support to enhance rural women productivity in the study area.
\end{abstract}

\section{Keywords}

Agriculture, food production, land tenure, seeds, traditional implements, rural women

\section{Introduction}

When women went and the days as a group of farmers were being maligned for the ironmen's of little contribution and as an appendage. Women are found working round the year, producing food crops, while men perform only replanting tasks in some occasions [1]. Similar assertion was held by the World Bank [2] and National Bureau of Statistics [3] which given an estimate of 78\% of women in Africa, including Nigeria, are active in agriculture, compared with only 64\% of the men. Also, Okoli [4], Aneke and Alio [5] noted that there is a high acknowledgement of the role of women in agricultural development particularly after Nigerian's independence. In a nut-shell, Banji and Okunade [1] recorded that Oyo State women are 50\%, 98\%, 85\%, 91\%, 92\% and 79\% involved in planting, weeding, harvesting, transplanting, processing and marketing of agricultural produce respectively. In addition to their crucial roles in food production, women contribute to food security in other significant ways, such as by preserving biological diversity, 
processing and preparing food and caring for the basic needs of the household [2]. Their subsistence is, however seriously threatened by growing food demands. Given that women are responsible for the bulk of food production as providers of food security and meaningful contributors to family incomes, any attempt to eradicate poverty should acknowledge their role as producers of food and income-earners [8]. Thirtle et al. [9] in empirical observations explored the relationship between agricultural productivity and poverty between 1985 and 1993 in 48 developing countries and findings showed that a $1 \%$ improvement in agricultural produce reduced the proportion of people living on less than USD \$1 per day by between 0.6 and 1.2 percent. Development of the agricultural sector is especially crucial to alleviating poverty in developing countries, where a large proportion of Gross Domestic Product (GDP) is generated within the primary sector by rural women. For example, Alston et al. [10] opined that agricultural development is up to four times more effective in reducing poverty relative to growth in other sectors, and growth in rural peasant agricultural productivity has been shown to have a positive impact on both urban and rural populations in three key ways: a) lower food prices for consumers; b) higher incomes for producers; and c) growth multiplier effects through the rest of the economy as demand for other goods and services increases. A number of economic roles are provided by agriculture as semi-externalities or public goods. These are functions which may not exist without agricultural production, but which producers are not compensated. For instance, agriculture provides a number of welfare enhancing, income transfer and income-shock buffer functions.

Women perform some $90 \%$ of the work of food processing, $80 \%$ of food storage tasks, and $60 \%$ t of harvesting and marketing; they play a key role in food production, food security and the sustainability of Nigeria economy [8]. Notwithstanding, the women farmers' contributions and level of participation in the different agricultural activities across the nation, their impact on agriculture is still leaving noticeable snags in the nation's future food supply. Hence, this study investigated the level of rural women's contribution to agriculture in relation to their household responsibilities.

\section{Objective of the study}

The broad objective of the study is to critically examine women farmers' contributions to agricultural production in the study area while the specific objectives were to:

i. determine the socio-economic characteristics of the women farmers' in the study area;

ii. ascertain the accessibility of the respondents to selected production inputs;

iii. identify the farming methods and operations; and

iv. estimate the domestic activities of the women farmers and time spent per day on each of these activities.

\section{Hypothesis of the study}

$\mathbf{H}_{\mathbf{0 1}}$ : There is no significant positive relationship between women farmers' socio-economic characteristics and their level of participation in farming.

\section{Methods}

\subsection{Design and Sample}

The study was carried out in Akinyele Local Government area of Oyo State. The LGA is within longitude 30 45'E and $4^{\circ} \mathrm{E}$ and Latitude $7^{\circ} 45^{\circ} \mathrm{N}$ and $7^{\circ} 3^{\circ} \mathrm{N}$. It is bounded in the south by Ido Local Government, in the East by Lagelu Local Government and in the North by Afijio local government of Oyo State. The local government area consists of urban, peri-urban and rural communities. Basically, the residents are majorly framers while other livelihood activities on the study area are include trading, bricklaying, carpentry, and civil service job.

Crops grown in the area include maize, cassava, yam, cowpea and vegetables. Livestock found in the area include sheep, goats, cattle, poultry and pigs.

\subsubsection{Population sample size and sampling technique}

The population of the study includes all rural women in the study area. Women farmers in the study area were purposely selected. Simple random sampling technique was used in the selection of the communities through which 5 rural communities of Iroko, Onidundu, Ikereku and Olanla were sampled. Thirty women farmers were interviewed in each of the villages to arrive at 150 total numbers of respondents.

\subsubsection{Data analysis}

The data collected were analysed using both the descriptive and inferential statistics. The former include frequency distribution table and percentages, while the latter include linear regression, which aided the assessment of the relationships between women participation in agriculture and their socio-economic status. 


\section{Results}

\subsection{Description of socio-economic characteristics of the respondents}

The mean age of women farmers in the study area was found to be 42.03 years old, 31.3\% were $31-40$ years old, $42 \%$ were $41-50$ years old, and $16.7 \%$ were above 51 years. This shows that the women are still economically active and have strength to undertake agricultural activities. The average monthly income was $17,213.83$ but $34.7 \%$ and $22 \%$ realized 10,001-20,000 and 20,001-30,000 respectively. The average number of people in a household was five, many (58.7\%) of the respondents have 1-5 people in households while 30.7\% have 6-10 people in their households. This reflects that large household sizes are very common among the women in the rural areas. Similar finding was reported by Oyediran et al. [6] in a study conducted among rural households in Katsina State, Nigeria. The majority (71.3\%) was married and the rest were single (14.7\%), widows (8.7\%), and divorced (5.3\%). Field observations and interaction with the respondents revealed that most of the women use their income to support their children; few of them hand over their annual income to their husbands, while a small proportion of them save it for future investment.

\subsection{Accessibility to land and other production inputs}

Table 2 shows that fifty-six percent of the rural women acquired land through inheritance, 19.3\% through purchase, $15.3 \%$ and $9.4 \%$ through least and as a gift from people respectively. This suggests that a good number of the women in the study area have access to land from their parents. An assessment of the size of farms of the respondents revealed that $65.3 \%$ had farm size of $1-5$ acres, $22 \%$ had up to $6-10$ acres, while only $12.7 \%$ had more than 11 acres. These findings reveal that rural women are small farm holders and operate at subsistence level. This could be due to impact of inheritance of land which fragments and reduces the proportion of land available to a family member as land is transferred from generation to generation. Sikorska in Oyediran et al. [7] reported that agricultural land is becoming scarce in recent time. This scenario has affected mechanized farming in the study area. About half of the respondents (48.7\%) got their seeds through purchases from the open markets, 37.3\% got theirs from previous harvest, and 14\% from government agencies. This affirms the finding by Oyediran et al. [7] that most farmers in Nigeria used seeds from the previous harvest and purchase from the open markets. The reason is because farmers have complained that seeds government agencies are not readily available to them at the peak of farming season. It can therefore be deduced that majority of the farmers are predisposed to buying rather unviable seeds or poor yielding varieties. Also, $80.7 \%$ of the respondents use their personal savings as capital, while $11.3 \%$ are supported with credits by their husbands and very few (8\%) got financial assistance from the Commercial Banks and local money lenders. This finding agrees with Philip in Oyediran et al. [6] who also reported that rural women in Nigeria had little access to credit facilities.

\subsection{Farming methods and operations}

The results of the survey as presented in Table 3 revealed that mixed farming formed a single largest category among the women (46.7\%). This could be influenced by the complimentary role of crop and animal production practiced together. Some of the respondents (38.6\%) cultivated crops while $14.7 \%$ reared animals. These findings point to the fact that rural women contributed to the household food security and other basic needs of the family members through their participation in agriculture. It was observed that majority of the respondents (73.3\%) used simple hand tools such as hoes, knives, and cutlasses while $26.7 \%$ combined animal traction with simple hand tools. These findings point to traditional farming practices among the rural women. Table 3 further shows that majority (45.3\%) used self-labour, 24.7\% used family labour, $16.7 \%$ hired labour and $13.3 \%$ used community labour. The low patronage of hired labour as indicated in the result could be due to its high cost which in many cases the rural women could not be able to afford to pay. Oyediran et al. [6] opined that family labour is the cheapest in agriculture but not readily available which makes farmers go for the use of hired labour at the peak of farming season in Nigeria.

\subsection{Daily time use of women farmers between farming and domestic activities}

From Table 4, it was found that $62.7 \%$ of the respondents spent between 3-7 hours on household chores per day, while $23.3 \%$ spent more than 7 hours per day, but $14 \%$ spent less than 3 hours on household chore per day. This attributed to the long hours they spend on the farm per day. Women farmers that spend 3 hours are very few compared to are those that spend 7 hours and above.

\subsection{Test of hypothesis: socio-economic characteristics and level of participation in agriculture}

The result of the regression model tested at $5 \%$ level of significance revealed that age $(\beta=0.74)$, marital status $(\beta=$ $0.12)$, income $(\beta=0.18)$ and educational level $(\beta=0.81)$ were significant at $p<0.05$. But, family size $(\beta=-0.06)$ was found to be insignificant at $p<0.05$. This by implication means that all the aforementioned variables except family size are important and reliable indicators of what influenced participation of rural women in agriculture in Akinyele Local Government Area. The significant variables were also found to be positively related to the level of participation in 
agriculture. Family size is not significant because it does not translate to have more hands to work on the farm in the study area. This could be due to the fact that some families may be large enough but are composed of infants or very few female members who are the focus of this study.

\section{Discussion}

The estimated mean income of the respondents was $\$ 17,213.83$ (Table 1) which indicates that the rural women realized very little income from their participation in agricultural enterprise. Field observations and interaction with the respondents revealed that most of the women use their income to support their children; few of them hand over their annual income to their husbands, while a small proportion of them save it for future investment. Rural women do not have access to land and credits hence they are limited to subsistence farming (Table 2). Mixed farming predominates among the respondents while personal and family labour constituted major sources of farm labour (Table 3). Most of the respondents spent approximately 3 to 7 hours daily on domestic activities (Table 4); this reduces their manday on the farms. Also, socio-economic variables determined rural women participation in agriculture (Table 5).

\section{Conclusion}

This research has shown that women in the study area are active in agricultural production and they lack modern implements. Moreover, the women operate at subsistence level and used crude implements; and personal savings constituted the initial capital to start new farming seasons because the women had no access to banking/credit facilities. Majority of the women farmers acquired their land through inheritance and this prevents mechanization effort. In recognition of the vital role of women in socio-economic activities as well as in agricultural production which is a pre-requisite for successful rural development and increased agricultural productivity, this study recommends provision of agricultural inputs, goods, socio-economic services, time and labour saving machines to women, through non-discrimination channels to existing delivery systems are needed. Besides, meaningful education for women, like adult education, agricultural training and extension programmes to support women's participation in agricultural production, processing and marketing is also necessary. However, since this work has not exhausted all constraints of women farmers in the rural areas, but has briefly highlighted some important ones, there is the need for further research on the contributions of women to agriculture in Nigeria.

Table 1. Distribution of respondents according to women farmers' socio-economic characteristic in the study area $(n=150)$

\begin{tabular}{|c|c|c|c|}
\hline Women farmers' socio-economic characteristics & Frequency & Percentage & Mean \\
\hline \multicolumn{4}{|l|}{ Age (years) } \\
\hline less than 30 & 15 & 10.0 & \\
\hline $31-40$ & 47 & 31.3 & \\
\hline $41-50$ & 63 & 42.0 & 42.03 \\
\hline 51 and above & 25 & 16.7 & \\
\hline \multicolumn{4}{|l|}{ Monthly income ( } \\
\hline Below 10,000 & 44 & 29.3 & \\
\hline 10,0001 to 20,000 & 52 & 34.7 & \\
\hline 20,001 to 30,000 & 33 & 22.0 & $17,213.83$ \\
\hline 30,001 and above & 21 & 14.0 & \\
\hline \multicolumn{4}{|l|}{ No. of people in the household } \\
\hline $1-5$ & 88 & 58.7 & 5 \\
\hline $6-10$ & 46 & 30.7 & \\
\hline 11 and above & 16 & 10.6 & \\
\hline \multicolumn{4}{|l|}{ Marital Status } \\
\hline Single & 22 & 14.7 & \\
\hline Married & 107 & 71.3 & \\
\hline Widow & 13 & 8.7 & \\
\hline Divorced & 08 & 5.3 & \\
\hline
\end{tabular}

Field Survey, 2018 
Table 2. Distribution of respondents according to production inputs utilization in the Study Area $(\mathbf{n}=150)$

\begin{tabular}{|c|c|c|}
\hline Mode of land acquisition & Frequency & Percentage \\
\hline Inheritance & 84 & 56.0 \\
\hline Purchase & 29 & 19.3 \\
\hline Lease & 23 & 15.3 \\
\hline Gift & 14 & 9.4 \\
\hline \multicolumn{3}{|l|}{ Farm size (acre) } \\
\hline $1-5$ & 98 & 65.3 \\
\hline $6-10$ & 33 & 22.0 \\
\hline 11 and above & 19 & 12.7 \\
\hline \multicolumn{3}{|l|}{ Source of seeds for planting } \\
\hline Purchase & 73 & 48.7 \\
\hline Previous year harvest & 56 & 37.3 \\
\hline Government credit & 21 & 14.0 \\
\hline \multicolumn{3}{|l|}{ Source of credit } \\
\hline Personal savings & 121 & 80.7 \\
\hline Husband & 17 & 11.3 \\
\hline Credit & 12 & 8.0 \\
\hline
\end{tabular}

Field Survey: 2018

Table 3. Distribution of respondents according to farming methods and operations in the Study Area $(n=150)$

\begin{tabular}{ccc}
\hline Agricultural System & Frequency & Percentage \\
\hline Crop production & 58 & 38.6 \\
Animal production & 22 & 14.7 \\
Mixed farming & 70 & 46.7 \\
Type of implements use & 110 & 73.3 \\
Hand tools & 40 & 26.7 \\
Hand tools and Animal & & 45.3 \\
Labour source & 68 & 24.7 \\
Self & 37 & 16.7 \\
Family & 25 & 13.3 \\
Communal & 20 & \\
\hline
\end{tabular}

Field Survey, 2018

Table 4. Distribution of respondents according to daily time use of women farmers btw farming and domestic activities (n = 150)

\begin{tabular}{ccc}
\hline Hours spent per day & Frequency & Percentage \\
\hline Less than 3 & 21 & 14.0 \\
$3-7$ & 94 & 62.7 \\
Above 7 & 35 & 23.3 \\
Labour source & & 52.0 \\
Self & 78 & 31.3 \\
Family & 47 & \\
\hline
\end{tabular}




\begin{tabular}{|c|c|c|c|}
\hline Hired & & 15 & 10.0 \\
\hline Communal & & 10 & 6.7 \\
\hline \multicolumn{4}{|c|}{ Field Survey, 2018} \\
\hline \multicolumn{4}{|c|}{ Table 5. Regression result on socio-economic characteristics of women farmers and their participation in agriculture } \\
\hline Variables & Parameter & t-ratio & \\
\hline Age & 0.74192 & $3.523^{*}$ & \\
\hline Marital Status & 0.119543 & $2.116^{*}$ & $\mathrm{Df}=95$ \\
\hline Income & 0.179111 & $4.504^{*}$ & R-square $=0.3368$ \\
\hline Educational Level & 0.810472 & $3.994^{*}$ & \\
\hline Family size & -0.0646991 & $-2828^{\mathrm{ns}}$ & F-value $=9.547$ \\
\hline Constant & 0.351636 & 2.900 & \\
\hline
\end{tabular}

Field survey; $2018{ }^{*}=$ significant at $5 \%$ level of significance, ns $=$ non significance

\section{Acknowledgements}

This paper acknowledged the support of Management of the Federal College of Education (Special), Oyo, Oyo State, Nigeria, extension agents, contact farmers, rural women in Akinyele LGA, and the enumerators. We say a big thank you to you all.

\section{References}

[1] Banji, O. A. and Okunade, E. O. (2011). Women in agriculture and rural development. Agricultural Extension Society of Nigeria Journal. 90-100.

[2] World Bank. (2010). Agricultural Technology and Agribusiness Advisory Services Project. Agriculture and Rural Development African Region. Kampala, Uganda.

[3] National Bureau of Statistics. (2012). LSMS: Integrated surveys on Agriculture: General Household Survey panel 2010/11.

[4] Okoli, T. O. (2011). Training needs for women for effective performance on agriculture in Anambra State. Unpublished Ph.D Thesis Department of Tech. and Voc. Education, ESUT.

[5] Aneke, C. U. and Alio, A. N. (2018). Women participation in agriculture a prospect and challenges for increased food production on Enugu State-Nigeria. British Journal of Education, Vol. 6(11), 29-35.

[6] Oyediran, W. O., Omoare, A. M., and Osinowo, O. A. (2017). Contributive roles of sorghum production to food security and economic empowerment of rural farming households in Katsina State, Nigeria. Canadian Journal of Agriculture and Crops, 2(1), 42-49.

[7] Oyediran, W. O., Omoare A. M., and Ajagbe, B. O. (2016). Factors affecting sustainability of melon (egusi) production in rural farming households of southwest, Nigeria. American Journal of Agricultural Research, 1(1), 001-0010.

[8] Oyediran, W. O., Omoare, A. M., Olanrewaju, O. O., and Abubakar, A. A. (2018). Implication of Technology Adoption on Economic Returns of Melon Processors in North Central, Nigeria. Annals of Advanced Agricultural Sciences (AS), 2(3), 31-36.

[9] Thirtle, C., Lin, L., and Jennifer, P. (2003). The impact of research-led agricultural productivity growth on poverty reduction in Africa, Asia and Latin America. World Development, 31(12), 1959-1976.

[10] Alston, J., Beddow, J., and Pardey, P. (2008). Agricultural research, productivity, and food commodity prices. Agricultural and Resource Economics Update, 12(2), 11-14. 